\title{
Good sensory quality and cheesemaking properties in milk from Holstein cows managed for an 18-month calving interval
}

\author{
G. M. Maciel, ${ }^{* 1}$ N. A. Poulsen, ${ }^{*}$ M. K. Larsen, ${ }^{*}$ U. Kidmose $†$ C. Gaillard, $\ddagger$ J. Sehested, $\ddagger$ and L. B. Larsen* \\ *Department of Food Science, Aarhus University, Blichers Allé 20, 8830 Tjele, Denmark \\ †Department of Food Science, Aarhus University, Kirstinebjergvej 10, 5792 Årslev, Denmark \\ ‡Department of Animal Science, Aarhus University, Blichers Allé 20, 8830 Tjele, Denmark
}

\section{ABSTRACT}

Extended calving interval (CInt) for high-yielding dairy cows beyond the traditional 12 mo has been suggested as a profitable, environmentally and welfarefriendly production strategy. However, concerns exist on whether extending cow CInt, and consequently prolonging lactation length, impairs milk quality. The aim of this study was to compare the quality of milk produced during the extended lactation period to mid lactation. In particular, milk indicators related to udder integrity and cheesemaking properties when cows were fed low- or high-energy diets in early lactation mobilization period. Forty-seven healthy Danish Holstein cows (15 primi- and 32 multiparous) were fed 2 distinct weight-adjusted diets in early lactation: either a high-density diet for approximately $42 \mathrm{~d}$ in milk (DIM) followed by a low-density diet $(\mathrm{n}=22)$, or a low-density diet throughout the whole experiment (n $=25$ ). Milk quality was explored at 3 lactation periods: 140 to 175 DIM (P1), 280 to 315 DIM (P2), and 385 to 420 DIM (P3). Lactation period was found to be the main factor affecting milk yield, quality, and cheesemaking properties. Primiparous cows kept the same daily milk yield throughout the studied periods, whereas multiparous cows produced, on average, 10.2 $\mathrm{kg} / \mathrm{d}$ less in P3 compared with P1. Fat, protein, and casein concentrations increased, respectively, by 18 , 16 , and $16 \%$, from P1 to P3. Cheesemaking properties, such as curd-firming rate, gel strength, and wet and dry curd yield, got an improvement from P1 to P3 and were strongly correlated with milk concentrations of protein and casein. The udder integrity indicators, somatic cells count, level of free amino terminals as an index of proteolysis, and milk $\mathrm{pH}$, remained unchanged throughout the studied lactation periods. Feeding cows either high- or low-density diets during the early lac-

Received January 28, 2016.

Accepted July 15, 2016.

${ }^{1}$ Corresponding author: maciel@food.au.dk tation mobilization period did not exert any relevant carryover effect on milk composition, and thus had no effect on cheesemaking properties in extended lactation. Further, sensory quality of mid- and extendedlactation milk was assessed by a trained sensory panel. The sensory quality of milk from P3 reflected sensory descriptors related to the increased levels of fat and protein over lactation, but, importantly, milk produced in P3 did not present sensory demerits when compared with milk produced in P1. In conclusion, high-yielding Holstein cows undergoing an 18-mo CInt produced high-quality milk from mid to extended lactation.

Key words: milk coagulation, automatic milking system, individual feeding strategy, extended lactation

\section{INTRODUCTION}

Extended lactation is a production strategy in which rebreeding is deliberately delayed maximize lactation persistency rather than peak production (Sorensen et al., 2008). In many production systems, dairy cows calve once a year, usually achieving three 12 -mo calving intervals (CInt) during their lifetimes (Knight, 2005). Extending the lactation period beyond the 12-mo CInt has been suggested as an alternative strategy, and its potential to better exploit modern dairy cow production capacity has been investigated in pasture-based (Kolver et al., 2007), seasonal-grazing (Österman and Bertilsson, 2003; Lehmann et al., 2016), and all-year barn-feeding dairy production systems (Lehmann et al., 2016).

By extending CInt, the number of calves per cow per year is reduced and, accordingly, so is the susceptibility to calving risks and postpartum metabolic disease (Knight, 2005; Sorensen et al., 2008). It is also suggested that fewer calves per cow per year results in reduction of number of dry days per cow per year, replacement heifers, and feed use, thereby potentially lowering greenhouse gas emissions per kilogram of milk produced (Lehmann et al., 2014). Furthermore, some economic benefits may exist by extended lactation, such as reducing costs per cow regarding mating, calv- 
ing, animal health, and cow replacement (Borman et al., 2004).

Several studies have, to various degrees, covered milk production and compositional aspects in relation to lactation cycle duration (Österman and Bertilsson, 2003; Auldist et al., 2007, 2010; Kolver et al., 2007; Sorensen et al., 2008; Grainger et al., 2009), but studies on milk technological qualities from cows in extended lactation are scarce. Auldist et al. (2010) revealed that milk produced by Holstein-Friesian cows managed for a 24rather than a 12-mo CInt had superior fat and protein concentration, cheesemaking properties, and cheese yield. Increased milk solids were also found by Sorensen et al. (2008) for Holstein-Friesian cows managed for an 18-mo CInt; however, those authors observed a decrease in the casein-to-protein ratio during the extended lactation period, suggesting that this milk might not be as suitable for cheese manufacturing. Bertilsson et al. (1997) reported a salty taste in the milk produced by cows undergoing extended lactation, drawing attention to a possible sensory demerit. Such findings indicate a possible decline in the udder epithelial integrity when high yield is maintained for longer lactation periods. These changes are comparable to what is normally observed in milk from cows in late lactation, in which concentrations of salts, SCC, serum proteins, and proteases derived from both the plasmin-plasminogen system and somatic cells increase (Korycha-Dahl et al., 1983; Grufferty and Fox, 1988; Larsen et al., 2006); this may potentially result in increased protein hydrolysis as well as impaired cheesemaking and sensory properties (Lucey and Fox, 1992; Lucey et al., 1992; Auldist et al., 1996; Lucey, 1996).

Most of the publications reporting compromised suitability for dairy processing of late-lactation milk date back to the 1980s and '90s, when cows at dry-off had considerably lower yields and high-standard husbandry practices and nutritional plans were not customary. Thereby, these studies might not reflect management of modern high-yielding dairy cows. For instance, recent research has underlined the potential of individual over group feeding strategies for better attending individual energy demands (Bossen and Weisbjerg, 2009). Such a strategy has been proposed as a way to better exploit the productive potential of high-yielding Holstein cows without compromising milk composition. Gaillard et al. (2016c) verified that an individual weight-adjusted feeding strategy, supplying high-energy density diet in early lactation, reduced the magnitude of the mobilization period. But, conversely, cows fed by this strategy had lower lactation persistency compared with cows fed a low-energy diet during the entire extended lactation. However, the effect caused by individual feeding strate- gies on milk quality, with its implications for cheese processing, will be addressed in the present study.

Given the limited data on detailed composition and characteristics of milk produced during the extended lactation period, the aims of the present study were (1) to investigate possible changes in milk produced during the extended lactation period compared with milk produced in mid lactation of cows managed for an 18-mo CInt, by monitoring indicators related to udder integrity, cheesemaking properties, and sensory quality; and (2) to examine if feeding cows a high-energy diet during the early lactation mobilization period would exert a carryover effect on milk composition, and consequently on cheesemaking properties, in cows managed for an 18-mo CInt. We hypothesized that the milk quality would be reduced toward the end of the extended lactation, with implications on cheesemaking properties and sensory quality. In addition, supplying a high-energy diet in early lactation would not cause long-term changes on milk composition.

\section{MATERIALS AND METHODS}

\section{Facilities, Animals, and Feeding Strategy}

Sixty-two Danish Holstein cows from the Danish Cattle Research Centre (DKC, Tjele, Denmark), housed in a loose-housing system with slatted floor and cubicles with mattresses, and with access to an automatic milking unit (AMU; DeLaval AB, Tumba, Sweden) were followed from October 2012 to October 2014. The experiment was approved by The Animal Experiments Inspectorate under the Danish Veterinary and Food Administration (Glostrup, Denmark).

The cows were blocked according to expected calving date and parity and randomly allocated to 2 feeding strategies at calving (Gaillard et al., 2016b). In short, the high-low energy diet strategy (HD-LD) refers to cows that received a 50:50 forage-to-concentrate partial mixed ration with a high energy density (HD; 7.81 MJ of $\mathrm{NE}_{\mathrm{L}} / \mathrm{kg}$ of $\mathrm{DM}$ ) until they reached at least 42 $\mathrm{d}$ of lactation and a live weight gain $\geq 0 \mathrm{~kg} / \mathrm{d}$ on a 5 -d average, and then individually shifted to a diet with a lower energy density $\left(\mathbf{L D}, 7.49 \mathrm{MJ}\right.$ of $\mathrm{NE}_{\mathrm{L}} / \mathrm{kg}$ of $\mathrm{DM}$ ), consisting of 60:40 forage-to-concentrate partial mixed ration. Cows in the low-low energy diet (LD-LD) were fed the LD diet during the whole lactation. Diets were formulated using the NorFor model and standards (Volden, 2011). For both groups the mixed part of the diet was offered individually and ad libitum, and each cow was provided $3 \mathrm{~kg}$ of concentrate per day at the AMU. For detailed information on the feeding experiment and diet composition, see Gaillard et al. (2016b). 
Among the 62 experimental cows, 6 were culled due to Escherichia coli infection in mid lactation, 3 had clinical mastitis during the trial, and 6 presented noncoagulating milk (defined below) at first sampling, and were thus excluded from further collection. Finally, 47 cows, 15 primi- and 32 multiparous, that did not present clinical mastitis or noncoagulating milk during their whole lactations were selected for this study. This included 25 cows in the LD-LD group with a mean parity of 1.6, and 22 cows in the HD-LD group with a mean parity of 2.2. Insemination occurred at the first heat observed after 220 DIM, to achieve an 18-mo CInt. The selected cows conceived, on average, $238 \mathrm{~d}$ after entering the experiment at their prior calving and lactated for around $465 \mathrm{~d}$, regardless of treatments and parity. Finally, the cows were dried off 8 wk before expected calving, or if the average milk production dropped below $12 \mathrm{~kg}$ of milk/cow per day in 2 subsequent weeks.

A free cow traffic system for access to the AMU was used, and all cows had access to the same AMU during all the experimental period. Access to AMU was restricted for the cows until an expected time and yield since last milking had been achieved (Table 1). Milk yield was recorded by the AMU for every milking, and the records were then used to calculate the daily milk yield $(\mathrm{kg} / \mathrm{d})$; somatic cells were optically counted by an online cell counter (OCC, DeLaval AB) coupled to the AMU at each milking. Each week, representative milk samples were taken from each cow, over a 48-h period, to be analyzed for fat, lactose, and protein concentrations by infrared spectroscopy (MilkoScan 4000, Foss Analytical, Hillerød, Denmark) at Eurofins Laboratories (Holstebro, Denmark). These results were used to calculate the ECM $(3.14 \mathrm{MJ} / \mathrm{kg})$ according to the equation proposed by Sjaunja et al. (1991), with ECM and milk yield in kilograms, and fat, protein, and lactose in grams per kilogram:

$$
\begin{aligned}
\mathrm{ECM}= & \text { milk yield } \times(38.3 \times \text { fat }+24.2 \times \text { protein } \\
& +15.71 \times \text { lactose }+20.7) / 3.140
\end{aligned}
$$

\section{Milk Composition}

For analysis of detailed milk composition, milk indicators of udder integrity, and cheesemaking properties, a representative milk sample of $1 \mathrm{~L}$ was collected from each cow during the first milking occurring after 0500 $\mathrm{h}$, respecting the rules given in Table 1. Individual milk samples were collected 3 times for each cow, at the following lactation periods: 140 to 175 DIM (P1), 280 to 315 DIM (P2), and 385 to 420 DIM (P3). The 3 lactation periods were defined to represent distinct times of an extended lactation cycle. Period 1 was assigned to define the period at mid lactation after peak production, at a time where no cows were pregnant. Period 2 denotes the period when all cows were up to 10 wk in pregnancy, analogous to the stage when cows undergoing a typical 12-mo CInt are dried off. Period 3 represented the last fifth of the extended lactation period when cows were still producing relatively high yields of milk, corresponding to $9 \pm 3$ wk to dry off or $17 \pm 3$ wk before next calving.

Milk samples were cooled immediately to $4^{\circ} \mathrm{C}$ and subsequently analyzed for overall milk composition (fat, protein, casein, and lactose) using an in house Milkoscan FT2 (Foss Analytical). All samples were skimmed to $\leq 0.1 \mathrm{~g}$ of fat $/ 100 \mathrm{~g}$ of milk by centrifugation at $2,643 \times g$ for $30 \mathrm{~min}$ at $4^{\circ} \mathrm{C}$ followed by measurements of pH using a PHM $220 \mathrm{pH}$ meter (RadioMeter, Copenhagen, Denmark). Conductivity was assessed via a LDM 210 conductivity meter (RadioMeter). Chloride concentration in skim milk samples was determined using an automated potentiometric titrator (Metrohm 862, Metrohm, Herisau, Switzerland). Briefly, skim milk samples were heated to $40^{\circ} \mathrm{C}$ in a water bath, gently mixed, cooled to room temperature, and $10 \mathrm{~g}$ were transferred to a vessel. The vessels were filled with 80 $\mathrm{mL}$ of demineralized water, with a subsequent addition of $10 \mathrm{~mL}$ of $4 \mathrm{MHNO}_{3}$, and then titrated using a standardized 0.1 $\mathrm{M} \mathrm{AgNO}_{3}$ solution against an Ag-Titrode (Metrohm).

Level of free amino terminals was determined in individual skim milk samples by the fluorescamine

Table 1. Allowance conditions to the automatic milking unit (AMU)

\begin{tabular}{lcccc}
\hline & \multicolumn{2}{c}{ Either } & & \multicolumn{2}{c}{ Or } \\
\cline { 2 - 3 } \cline { 5 - 5 } Days & Hours from last milking & & Expected milk yield (kg) & Manual pick-up ${ }^{1}(\mathrm{~h})$ \\
\hline 0 to 330 DIM & 5 & 7 & 15 \\
330 DIM to 70 DEC & 8 & 8 & 15 \\
70 DEC to drying-off & 12 & 10 & 20 \\
\hline
\end{tabular}

${ }^{1}$ If the time from last milking exceeds those values, the cow is conduced to the AMU.

${ }^{2}$ Days to expected calving. 
method as described by Dalsgaard et al. (2007). The method expresses the level of free amino terminals in the samples as leucine equivalents (in $\mathrm{m} M$ ) according to a standard curve for leucine. All milk compositional analyses were performed in triplicates.

\section{Cheesemaking Properties}

Milk coagulation properties were measured using a ReoRox4 oscillatory rheometer (MediRox AB, Nykoping, Sweden) by continuous monitoring of the chymosin-induced milk coagulation, as described previously (Frederiksen et al., 2011). Individual skim milk samples were adjusted to $\mathrm{pH} 6.50 \pm 0.02$ by addition of $10 \%$ (vol/vol) lactic acid before analysis to eliminate the potential effect of differences in milk $\mathrm{pH}$ on the coagulation process. Subsequently, the samples were preincubated in a water bath at $33^{\circ} \mathrm{C}$ for $30 \mathrm{~min}$ before addition of 0.04 international milk clotting units of ChyMax Ultra (Chr. Hansen Laboratories A/S, Hørsholm, Denmark) per milliliter of skim milk. Rheological measurements were performed at $33^{\circ} \mathrm{C}$ for $60 \mathrm{~min}$. Rennet coagulation time (RCT, in min), maximum gel strength ( $\mathbf{G}^{\prime} \mathbf{m a x}$, in $\mathrm{Pa})$, and curd-firming rate $\left(\mathbf{C F R}\right.$ as $\left[\Delta \mathrm{G}^{\prime} / \Delta \mathrm{t}\right]_{\mathrm{lin}}$, in $\mathrm{Pa} / \mathrm{min})$, where $\Delta \mathrm{G}^{\prime}$ is the change in storage modulus and $\Delta t$ is the change in time, calculated between 3 consecutive points of the linear part of the storage modulus curve after RCT is achieved, were selected to describe the milk coagulation properties (Frederiksen et al., 2011).

Wet and dry curd yield was estimated using the method by Hurtaud et al. (1995) with minor modifications. Skim milk samples were heated and kept in water bath at $35^{\circ} \mathrm{C}$ for $1 \mathrm{~h}$. Twenty milliliters of skim milk was transferred to 50-mL Falcon tubes (Sarstedt, Nümbrect, Germany) and the exact weight of the skim milk was noted. Thereafter, samples were placed in water bath for 30 min to reach $35^{\circ} \mathrm{C}$. Milk coagulation was initiated with the addition of 0.04 international milk clotting units/mL of milk of ChyMax Ultra (Chr. Hansen Laboratories A/S) and immediate stirring by vortexing for $3 \mathrm{~s}$ without foaming. The samples were then placed in a water bath at $35^{\circ} \mathrm{C}$ for $60 \mathrm{~min}$, and subsequently centrifuged at $35^{\circ} \mathrm{C}$ for $15 \mathrm{~min}$ at 2,700 $\times g$. Thereafter, the whey was discarded from the samples and the tubes containing the pressed curds were weighed and freeze-dried (ScanVac model CoolSafe Pro 100-4, LaboGene ApS, Lynge, Denmark) to obtain the wet and the dry curd weight. The wet curd yield was expressed in relation to the amount of skim milk as grams of curd per $100 \mathrm{~g}$ of milk, and the dry curd yield as grams of curd DM per $100 \mathrm{~g}$ of milk DM. Further, a protein transition number was defined as grams of curd DM per $100 \mathrm{~g}$ of milk protein. All cheesemaking properties analyses were performed in duplicates.

\section{Sensory Analysis}

For sensory analysis, milk samples from 6 cows in P1 and 6 cows in P3 were taken randomly at one occasion, and $0.5 \mathrm{~L}$ of the collected milk was pasteurized in a water bath at $65 \pm 2^{\circ} \mathrm{C}$ for $7 \mathrm{~min}$. Then, the samples were cooled in an ice bath and stored at $4^{\circ} \mathrm{C}$ for $24 \mathrm{~h}$ before the descriptive sensory analysis. Apart from the 12 individual milk samples, 2 pooled samples were also prepared by mixing the individual milk of the cows in $\mathrm{P} 1$ and $\mathrm{P} 3$, respectively, in equal proportions right before the sensory tests.

A trained sensory panel of 8 assessors ( 6 women and 2 men between 28 to 58 yr old) was used for sensory descriptive analysis. Prior to the sensory evaluation, the assessors attended a discussion and a training session (2 h each). During discussion and training, the panel was introduced to 5 milk samples $(2 \mathrm{P} 1,2 \mathrm{P} 3$, and 1 pooled sample) as well as reference samples (whole milk, cream, coffee cream, popcorn aroma and flavor, cardboard aroma and flavor, and stored flavor) produced as described by Hedegaard et al. (2006). A list of 12 sensory descriptors including aroma (cardboard, stored, metallic, and creamy), appearance (color saturation and yellowness), flavor or taste (faded, metallic, cardboard, creamy, and sweetness), and mouth feeling (creaminess) was agreed upon by the panelists before the evaluation.

During training and evaluation, the milk samples were randomly served in small plastic beakers with lids (Abena A/S, Aabenraa, Denmark) in amounts of approximately $50 \mathrm{~mL}$ after being kept at $12^{\circ} \mathrm{C}$ for 1 h. The sensory evaluation of the 14 milk samples was carried out in 3 replicates and in 6 blocks with breaks in between them on 2 consecutive days. The attributes were evaluated on a $15-\mathrm{cm}$, nonstructured, continuous scale and the ratings directly registered electronically (Fizz software, 2.30C, Biosystemes, Couternon, France). Training and evaluation were conducted in accordance with the International Organization for Standardization (ISO, 1993), and carried out in a sensory laboratory fulfilling the requirements provided by the American Society for Testing and Materials (ASTM, 1986).

\section{Data Analysis}

Lactation curves were produced by smoothing the milk yield (as ECM/d) data using the R-package fda in the software $\mathrm{R}$, version 3.1.2 ( $\mathrm{R}$ Development Core 
Team, 2015), following the procedure described by Gaillard et al. (2016c). The spline functions of the fda package are constructed by joining polynomials end-toend at argument values, called knots (here the knots are the DIM). These functions smooth on the integral of the squared deviations from an arbitrary differential operator. In the presented curves, the degree of smoothing was adjusted by applying a penalty of $1 \mathrm{e}^{+4}$ to the second derivatives of polynomials of order 4 .

To study the alterations in the milk yield, milk composition, milk indicators of udder integrity, and cheesemaking properties the following linear mixed model was used:

$$
\begin{aligned}
\mathrm{Y}_{\mathrm{ijkl}}= & \mu+\mathrm{P}_{\mathrm{i}}+\mathrm{F}_{\mathrm{j}}+\mathrm{W}_{\mathrm{k}}+(\mathrm{PF})_{\mathrm{ij}}+(\mathrm{PW})_{\mathrm{ik}} \\
& +(\mathrm{FW})_{\mathrm{jk}}+(\mathrm{PFW})_{\mathrm{ijk}}+\mathrm{C}_{1}+\varepsilon_{\mathrm{ijkl}},
\end{aligned}
$$

where $\mathrm{Y}_{\mathrm{ijkl}}$ is the dependent variable; $\mu$ is the overall mean; $\mathrm{P}_{\mathrm{i}}$ is the effect of parity ( $\mathrm{i}=$ primi- or multiparous); $F_{j}$ is the effect of feeding strategy ( $j=L D-L D$ or HD-LD); $\mathrm{W}_{\mathrm{k}}$ is the effect of the lactation period ( $\mathrm{k}$ $=\mathrm{P} 1, \mathrm{P} 2$ or $\mathrm{P} 3)$; parentheses denote the interaction effects; $\mathrm{C}_{1}$ is the random cow effect $(1=1, \ldots, 47)$; and $\varepsilon_{\mathrm{ijkl}}$ is the model error. The model was fit using the function lme of the R-package nlme (Pinheiro et al., 2014). Interaction effects not statistically significant were removed based on standard $F$-test. The normality of the model's residuals was verified by both Q-Q plots inspection and Shapiro-Wilk test, generated by the Rfunctions qqplot and shapiro.test. The variables SCC, CFR, and wet and dry curd yield were transformed to their common logarithms before statistical analysis to normalize the residuals. Pairwise comparisons $(\alpha=$ 0.05) were performed using the function lsmeans implemented in the R-package lsmeans (Lenth and Harvé, 2015).

Pearson correlation between the studied variables and their significances $(\alpha=0.01)$ were generated using the R-package corrplot (Wei, 2013), and correlations $\geq-0.50$ or $\leq 0.50$ were considered as strong. To evaluate the assessors and sensory differences in the samples collected in P1 and P3, Bonferroni least significant difference test was performed using the software PanelCheck v. 1.4.0226 (www.PanelCheck.com). The data were analyzed using a mixed model 3-way ANOVA considering the effects of sample, replicates, and assessor, with the assessor and interaction effects as random (Tomic et al., 2009).

\section{RESULTS}

Figure 1 illustrates the modeled lactation curves in milk yield (as ECM/d) for the 47 selected cows by parity (primiparous or multiparous) and feeding strategy
(HD-LD or LD-LD). The lactation periods P1, P2, and P3 studied in this experiment are highlighted. A clear lactation peak was observed for multiparous, in particular for the HD-LD cows, before the diet shift (average shift day at 50 DIM), whereas lactation peak was absent in the lactation curves of primiparous, independent of diet. Primiparous cows had an overall lower production when compared with multiparous cows, but were able to keep a relatively constant level of milk production $(30.9 \mathrm{~kg}$ of $\mathrm{ECM} / \mathrm{d})$ throughout the lactation periods. Multiparous cows had a higher production in P1 (38.2 $\mathrm{kg}$ of $\mathrm{ECM} / \mathrm{d}$ ) in comparison to primiparous cows, but they displayed a noticeable drop in milk yield $(10.7 \mathrm{~kg}$ of $\mathrm{ECM} / \mathrm{d})$ from $\mathrm{P} 1$ to $\mathrm{P} 3(P<0.0001)$, resulting in lower yield in P3 compared with primiparous cows. In addition, in $\mathrm{P} 3$ the milk yield of cows supplied LD-LD was higher than the yield of cows supplied HD-LD ( $P$ $<0.0001$ ), on average $5.5 \mathrm{~kg}$ of ECM/d, irrespective of parity.

Table 2 shows the effects of lactation period, feeding strategy, and parity on milk compositional traits and milk indicators of udder integrity. Lactation period significantly influenced lactose, fat, and protein concentrations. Fat, protein, and casein concentrations progressively increased from P1 to P3, accounting for 18,16 , and $16 \%$ increases, respectively; however, caseinto-protein ratio decreased from $\mathrm{P} 1$ to $\mathrm{P} 2$. Lactation period did not significantly affect $\mathrm{pH}$, conductivity, free amino terminals, or SCC, but chloride concentration was higher in P3 compared with P1 and P2.

The initial feeding strategy significantly affected the lactose concentration (Table 2), which was $0.04 \mathrm{~g} / 100$ g lower for cows fed HD-LD in comparison to cows fed LD-LD. The interaction between lactation period and feeding strategy indicated that changes for lactose concentration and milk yield followed the same pattern: it progressively reduced from P1 to P3 for HD-LD cows (4.81 vs. $4.69 \mathrm{~g} / 100 \mathrm{~g}$ of milk), whereas a marginal variation was observed for LD-LD cows (4.81 to 4.78 $\mathrm{g} / 100 \mathrm{~g}$ of milk).

Overall, cows fed HD-LD also presented significantly higher SCC $\left(31 \times 10^{3}\right.$ cells $/ \mathrm{mL}$ higher, on average $)$ when compared with cows fed LD-LD (Table 2). However, SCC was affected by the existing interaction between lactation period and feeding strategy. The SCC decreased from P1 to P3 for the LD-LD group (60 to $128 \times 10^{3}$ cells $/ \mathrm{mL}$ ), whereas no changes were observed over the studied periods for the HD-LD group $(110 \times$ $10^{3}$ cells $/ \mathrm{mL}$, on average). Regarding the interaction between feeding strategy and parity, the highest SCC values were found for the multiparous HD-LD and primiparous LD-LD groups (150 and $123 \times 10^{3}$ cells/ $\mathrm{mL}$ ), and primiparous HD-LD and multiparous LD-LD (71 and $72 \times 10^{3}$ cells $/ \mathrm{mL}$ ) presented the lowest levels. 
Table 2. Least squares means of the composition of milk produced by Danish Holstein cows managed for extended lactation at different lactation periods

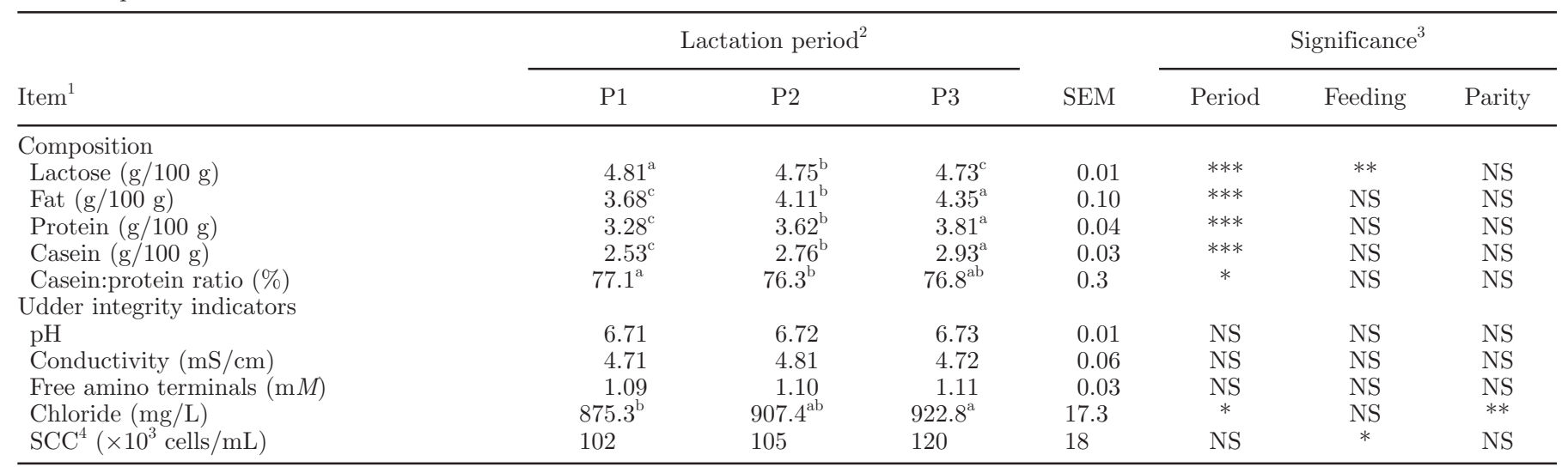

${ }^{\mathrm{a}-\mathrm{c}}$ Means within a row with different superscripts differ $(P<0.05)$.

${ }^{1}$ Free amino terminals expressed as leucine equivalents in $\mathrm{m} M$.

${ }^{2} \mathrm{P} 1=140$ to 175 DIM; P2 $=280$ to 315 DIM; and P3 = 385 to 420 DIM.

${ }^{3}$ Interaction effects were not removed from the model for lactose (lactation period $\times$ feeding strategy; $P=0.01$ ) and SCC (lactation period $\times$ feeding strategy, $P=0.02$; parity $\times$ feeding strategy, $P=0.02)$.

${ }^{4}$ Significance based on the common logarithm of SCC.

${ }^{*} P<0.05 ; * *<0.01 ; * * * P 0.001$.

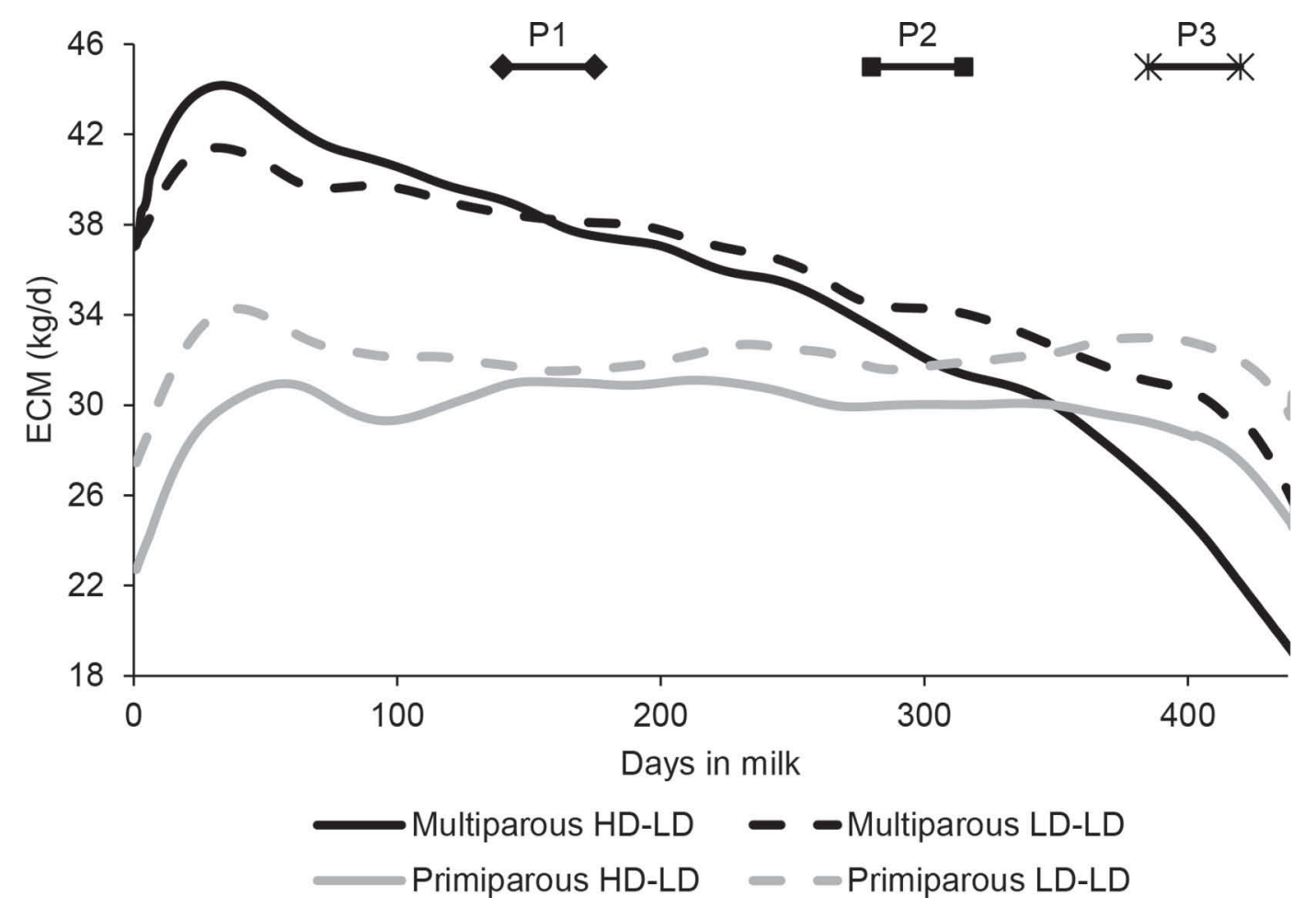

Figure 1. Smoothed lactation curves ( $\mathrm{kg}$ of ECM/d) of primiparous and multiparous Danish Holstein cows managed for an 18-mo calving interval and fed distinct diets during the mobilization period in early lactation. Milk analysis for detailed composition and cheesemaking properties were examined in different lactation periods: P1 (140 to 175 DIM), P2 (280 to 315 DIM), and P3 (385 to 420 DIM), as highlighted. HD-LD $=$ high density-low density partial mixed ration; LD-LD = low density-low density partial mixed ration. 
Parity significantly affected the chloride concentration, which was $11 \%$ higher for multiparous cows compared with primiparous cows (Table 2).

The development in cheesemaking properties through the 3 studied lactation periods are presented in Figure 2. Lactation period had a significant effect on rheological parameters (RCT, CFR, and $\mathrm{G}^{\prime} \max$ ) and curd yields. The RCT was significantly shorter in P3 compared with $\mathrm{P} 1$, and around $75 \%$ of the sampled milk coagulated within 20 min after chymosin addition in P3. The CFR increased with lactation period, with a major increase from $\mathrm{P} 2(8.5 \pm 0.6 \mathrm{~Pa} / \mathrm{min})$ to $\mathrm{P} 3(11.6$ $\pm 0.6 \mathrm{~Pa} / \mathrm{min})$. The $\mathrm{G}^{\prime} \max$ was significantly higher in P3 $(325 \pm 19 \mathrm{~Pa})$ when compared with $\mathrm{P} 1(185 \pm 19$ $\mathrm{Pa})$ and $\mathrm{P} 2(223 \pm 19 \mathrm{~Pa})$. A significantly higher wet curd yield was observed in P3 $(15.82 \pm 0.37 \mathrm{~g}$ of wet curd/100 g of milk) when compared with P2 (14.78 $\pm 0.36 \mathrm{~g}$ of wet curd/100 g of milk) and P1 (12.85 \pm $0.35 \mathrm{~g}$ of wet curd $/ 100 \mathrm{~g}$ of milk). A similar significant increase was also observed in the dry curd yield from $\mathrm{P} 1(3.55 \pm 0.67 \mathrm{~g}$ of curd DM/100 g of milk DM $)$ to P3 $(4.17 \pm 0.37 \mathrm{~g}$ of curd DM/100 g of milk DM). However, the transition number remained unchanged ( $103 \mathrm{~g}$ of dry curd/100 g of milk protein) across the studied periods.

A correlation heatmap of the analyzed compositional and cheesemaking parameters, milk indicators of udder integrity, and milk yield (in $\mathrm{kg} / \mathrm{d}$ ) are presented in Figure 3. Milk yield was strongly negatively correlated with protein concentration, whereas weak correlations were observed with udder integrity and cheesemaking parameters. Fat was strongly correlated with dry curd yield, protein, casein, G'max, and wet curd yield. Lactose was strongly negatively correlated with chloride concentration and strongly positively correlated with casein-to-protein ratio. Chloride concentration was also strongly correlated with conductivity and $\mathrm{pH}$. Protein and casein concentrations were strongly correlated with each other and with dry curd yield, wet curd yield, G'max, and CFR. Additionally, wet and dry curd yields were also strongly correlated with each other, as well as with CFR and G'max. Transition number was strongly correlated only to dry curd yield. Finally, RCT was negatively correlated only with CFR. Free amino terminals and SCC did not significantly correlate with any other parameter $(P>0.01)$ and were not included in the plot.

The sensory evaluation of pasteurized whole milk by the panelists for the individual and pooled milk samples of cows in P1 and P3, and their corresponding grades, are presented in Figure 4. The webplot clearly shows that milk from the 2 periods is evaluated differently. Compared with P3 milk, P1 milk presented higher average grades for attributes associated with off-flavors; cardboard aroma (3.4 vs. 2.0), stored aroma (4.4 vs. 2.9 ), faded flavor (6.2 vs. 4.5 ), and metallic flavor (5.9 vs. 4.2), although only metallic aroma (3.8 vs. 2.3 ) and cardboard flavor (4.2 vs. 2.3) were graded significantly higher. Contrarily, P3 milk had significantly higher grades than P1 milk for fat- and protein-related attributes as creamy flavor (7.9 vs. 5.6), creaminess (8.4 vs. 5.9), and yellowness (9.0 vs. 6.0 ).

\section{DISCUSSION}

A recent publication from Lehmann et al. (2016) has shown that managing cows for longer CInt can improve farm profitability in commercial herds. The success of such management inherently relies on feeding strategies' efficiency, to support lactation persistency (Borman et al., 2004). Nevertheless, it is important to address that feeding strategies must not have a negative effect on the processing and quality of the dairy products. Studies in the same experimental herd from which milk analyzed in the current experiment was sourced have covered the effect of early-lactation feeding strategies on the reproductive and productive performance of Danish Holstein cows managed for extended lactation (Gaillard et al., 2016a,b,c). Thus, this work has provided compositional, sensory, and cheesemaking characteristics of milk produced by cows managed for an 18-mo CInt fed different diets, aiming to minimize the effects of the mobilization period in early lactation.

The observed higher milk production for multiparous cows compared with primiparous is well-known, as multiparous cows have a higher energy intake as a consequence of a higher DMI (Gaillard et al., 2016b). Furthermore, superior lactation persistency for primiparous cows compared with multiparous has previously been reported for cows undergoing 12-, 15-, or 18-mo CInt (Rehn et al., 2000; Österman and Bertilsson, 2003). The steep decline observed here in milk production in the final part of the extended lactation period (i.e., 300 to 420 DIM) for multiparous cows diminishes the difference in overall production as a result of parity. Still, the total milk yield was higher for multiparous cows (Gaillard et al., 2016b).

Supplying a high-density diet in early lactation reduced the magnitude of the mobilization period (Gaillard et al., 2016c). It was expected that the HD-LD strategy would promote a carryover effect by increasing the milk yield and production persistency throughout the extended lactation cycle. This effect was not observed, as cows fed HD-LD had a faster decrease in milk yield from P1 to P3, and consequently poorer persistency, when compared with the group fed LD-LD (Gaillard et al., 2016b). Considering that the DMI was the same after and before diet shift in both groups $(P$ 
$>0.1$; Gaillard et al., 2016b), the poorer persistency could be a consequence of a negative carryover effect of the HD diet, as restricting diet energy after the shifting may lead to decreased mammary cell proliferation (Dessauge et al., 2011). The differential reaction to the HD-LD and LD-LD feeding strategies observed between primiparous cows indicates that those groups were not well balanced with respect to milk yield potential (Gaillard et al., 2016b).

During extended lactation, fat and protein concentrations in milk are not significantly affected by the level of diet energy (Grainger et al., 2009). Additionally,

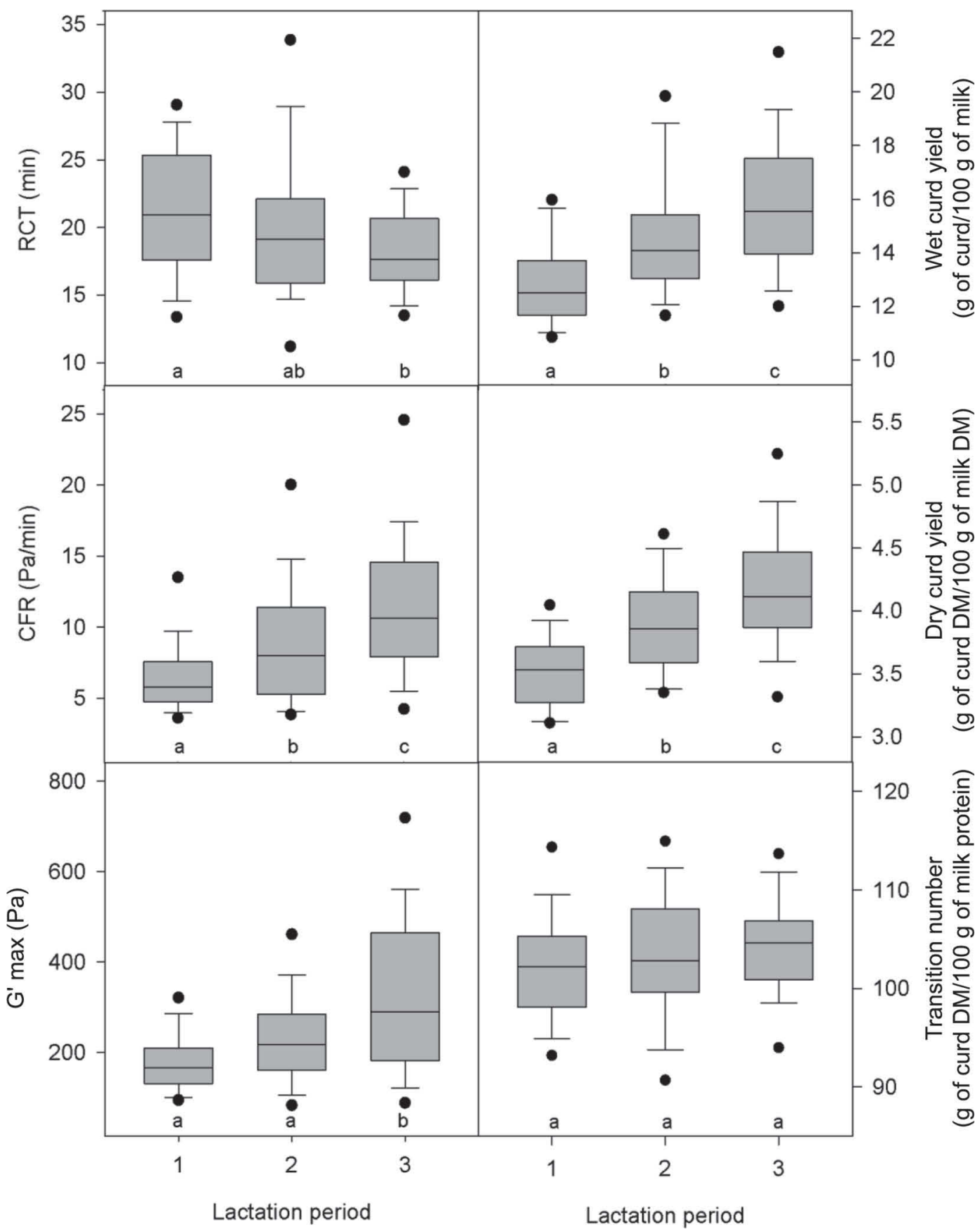

Figure 2. Changes in cheesemaking properties across the lactation periods P1 (140 to 175 DIM), P2 (280 to 315 DIM), and P3 (385 to 420 $\mathrm{DIM}) . \mathrm{RCT}=$ rennet coagulation time; $\mathrm{CFR}=$ curd-firming rate; G'max $=$ maximum gel firmness. The box indicates the 25 th and the 75 th percentiles, and the line within the box marks the median. Whiskers indicate the 10th and 90th percentiles and filled circles represent the 5th and 95th percentiles. Different letters $(\mathrm{a}-\mathrm{c})$ indicate significant differences based on $F$-test $(P<0.05)$. 


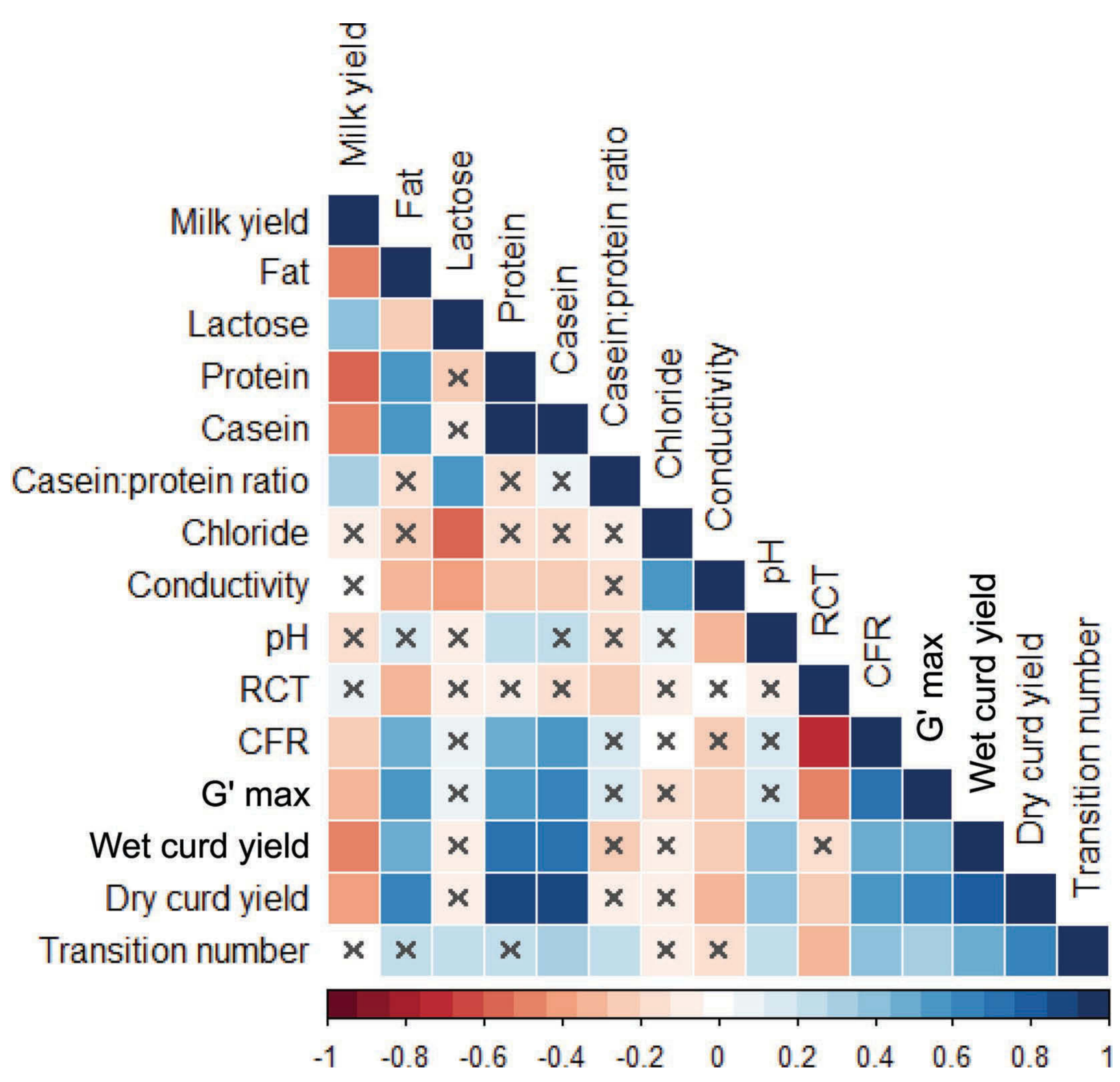

Figure 3. Pearson correlation heatmap between the milk composition parameters and cheesemaking properties from milk samples collected in the lactation periods studied. Correlations marked with a cross were not significant based on $F$-test $(P>0.01)$. RCT $=$ rennet coagulation time; $\mathrm{CFR}=$ curd-firming rate; $\mathrm{G}^{\prime} \max =$ maximum gel firmness. Color version available online.

Auldist et al. (2010) reported few differences in milk coagulation properties and cheese yield associated with diet energy level. We confirmed that the energy density of the diets offered during the mobilization period in early lactation did not significantly alter the concentrations of milk fat and protein during extended lactation. Moreover, the changes in lactose concentration and SCC were not large enough to affect milk quality and cheesemaking properties.

Milk became progressively more concentrated in late periods of extended lactation (P2 and P3) compared with mid lactation (P1), as observed by others (Österman and Bertilsson, 2003; Sorensen et al., 2008; Auldist et al., 2010). Declining milk yield and increasing concentrations of milk fat and protein occurring from lactation peak to drying off is well documented (Olori et al., 1997; Sorensen et al., 2008), irrespective of lacta- tion length and pregnancy status (Olori et al., 1997; Roche, 2003; Kolver et al., 2007). As the mammary tissue gradually fails to maintain its population of secretory epithelial cells due to cell apoptosis, the capacity of secreting milk diminishes and the solid components of milk and, consequently, concentrate (Olori et al., 1997; Stefanon et al., 2002). This mechanism might serve as an explanation to why differences were found between milk collected in P1 and P2.

On the other hand, at P3, the previously mentioned effect of lactation stage on milk yield and concentration of milk solids starts to be attenuated by the effect of pregnancy. Considering the fact that in the present experiment conception occurred, on average, at 238 DIM, in P2 (280-315 DIM) cows were in the beginning of their gestation when the effects of pregnancy on milk yield and composition are negligible (Coulon et al., 
1995; Olori et al., 1997; Coulon and Pérochon, 1998). Further, in P3 (385-420 DIM), cows were undergoing mo 4 to 6 of gestation, which most likely ascribes the changes noticed when comparing P3 to P2 and further to $\mathrm{P} 1$, as several authors have reported a noteworthy effect of pregnancy on milk yield and solids concentration from mo 4 to 6 of gestation onwards (Olori et al., 1997; Coulon and Pérochon, 1998; Roche, 2003). This effect of pregnancy on the mammary gland function is attributed to both nutrient partition and an increase in the blood circulation of fetal-placental hormones as the fetus grows larger, although the mechanisms have not yet been elucidated (NRC, 2001; Stefanon et al., 2002).

During late and extended lactation, the barrier between milk and blood is compromised, favoring the paracellular transport of blood constituents to milk (Athie et al., 1996; Sorensen et al., 2008). Thus, the milk produced could present increased proteolytic activity, $\mathrm{pH}$, and conductivity due to an increased concentration of $\mathrm{Na}^{+}$and $\mathrm{Cl}^{-}$(Nicholas et al., 2002), a higher concentration of whey proteins derived from the blood serum (Auldist et al., 1995; Stelwagen, 2002; Larsen et al., 2006), and an increasing number of somatic cells and blood-derived enzymes, including components from the plasmin system (Politis, 1996) linked to casein hydrolysis and a reduction on the casein-to-protein ratio (Sorensen et al., 2008).

The lack of changes from P1 to P3 in SCC, conductivity, $\mathrm{pH}$, level of free amino terminals, and on the casein-to-protein ratio suggests that udder integrity is not impaired when cows keep moderately high yields. This

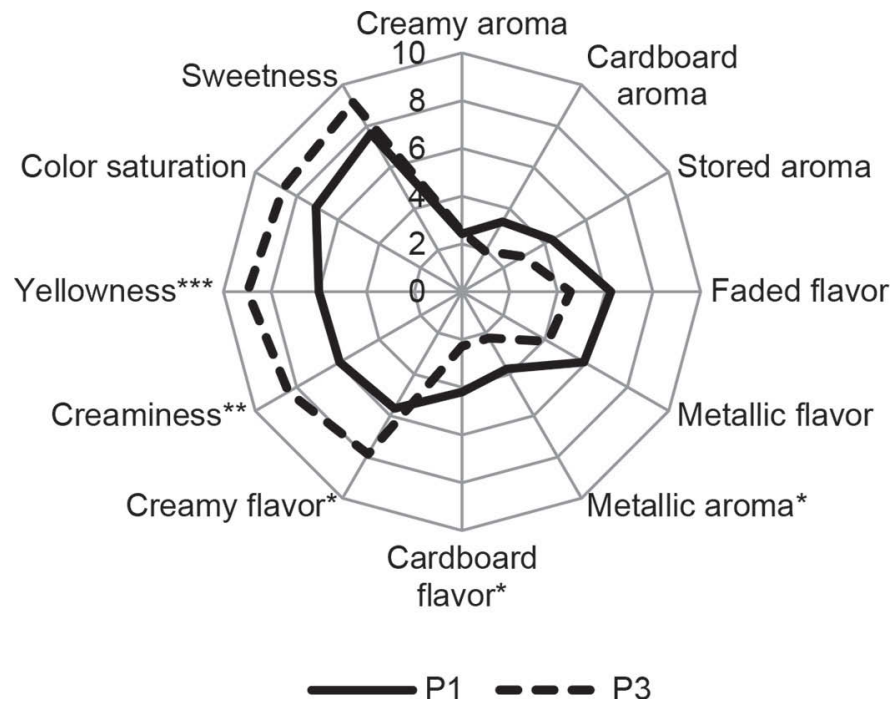

Figure 4. Cobweb plot of the sensory profiles of the milk from cows in lactation periods P1 (140 to 175 DIM) and P3 (385 to 420 DIM). Intensity scale: 0 (low) to 15 (high). Significant differences based on $F$-test are indicated by symbols: ${ }^{*} P<0.05,{ }^{* *} P<0.01$, and ${ }^{* * *} P<$ 0.001 . would also avoid situations that trigger an elevation in SCC due to incoming agents. Even though milking frequency was not increased at the end of the extended lactation to maintain SCC and casein-to-protein ratio at acceptable levels, as suggested by Sorensen et al. (2008), the quality of the milk produced between 385 and 420 DIM (P3) was at least comparable to the milk produced between 140 and 175 DIM (P1). We consider that higher production level of the cows in this experiment (see Gaillard et al., 2016b) compared with the experiment from Sorensen et al. (2008) could be one of the reasons for such differences.

The significant increase in concentration of milk chloride in P3 probably relates to a correlated countereffect to the decreased lactose concentration in milk, to keep its osmotic balance (Shennan and Peaker, 2000). Although we did not find evidence to attribute this increase to major mammary gland integrity changes, a significant correlation between the level of chloride and conductivity suggests a slight weakening of the tight junctions toward the end of the lactation. Such results corroborate with previous findings in which changes in milk composition only take place a few days to and after dry off (Athie et al., 1996; Capuco et al., 1997), when milk yield is considerably reduced.

Compositional changes occurring in milk at late lactation are often attributed to impaired cheesemaking properties, such as longer RCT, lower CFR and G'max, and reduced cheese yield (Lucey, 1996). Contrarily, Ostersen et al. (1997) and Coulon et al. (1998) reported that late-lactation milk (323 and 298 DIM) coagulated at a faster rate than mid-lactation milk (167 and 145 DIM), though in the latter study the gel strength was not superior for late-lactation milk despite the higher protein concentration. The same trends were found from P1 (140-175 DIM) to P2 (280-315 DIM), although the highest values for protein concentration, $\mathrm{CFR}$, and G'max and the shortest RCT were found at the later stage of the extended lactation (P3).

The RCT was negatively correlated with CFR, but no association was found for protein concentration, casein concentration, curd yield, dry curd yield, and transition number, in agreement with previous findings (Wedholm et al., 2006; Frederiksen et al., 2011). Although closely related in Danish dairy breeds, CFR was previously shown to be more dependent on protein concentration whereas RCT was more dependent on variations in $\mathrm{pH}$ at different lactation stages (Poulsen et al., 2015). Protein transition number (in grams of curd DM/100 g of milk protein) was not associated with any of the studied milk parameters or rheological parameters, though in a previous study it was shown to improve with increasing the casein-to-protein ratio (Wedholm et al., 2006). Besides, we found strong asso- 
ciations between the rheological parameters G'max and CFR with both wet and dry curd yields, as well as with protein and casein concentration. These correlations reveal that rheological parameters related to gel development and curd yield are more sensitive discriminators between lactation periods than RCT. Interestingly, we also found superior cheesemaking properties in the late period of the extended lactation (P3) when compared with mid lactation (P1). Similar findings were reported by Auldist et al. (2010), associated with the increasing concentration of milk proteins toward the end of lactation, which consequently improves casein aggregation (Guinee et al., 1997).

Elevated protein concentration in cheese milk has been suggested to increase the moisture of the final cheese, as it leads to the formation of a stiffer curd at cutting with a lower ability to rearrange and undergo syneresis (Guinee et al., 2006). However, Auldist et al. (2010) found similar moisture in cheddar cheese produced from milk collected at peak and at the last weeks of both normal and extended lactation, even though the latter milks contained higher protein levels. Our findings indicate that the elevated protein concentration in the later stages of the extended lactation did not influence curd moisture or protein transition number. This means that proteins were transferred equally well into the curd and, at the level of curd formation, exhibited the same water-binding capacity. Even though the measurements used in the present study were made in skim milk and only represent the early stages of the cheese manufacturing, laboratory cheesemaking processes have been considered as valid predictors for the yield and composition of cheeses produced further at the dairy (Hurtaud et al., 1995; Wedholm et al., 2006).

Adjusting the protein level of the cheese milk is a common practice at the dairies to enable a standardized time set for curd cutting based on time after rennet addition. This can potentially overcome high moisture in cheese made with milk containing very high protein levels. As consequence, even if the cheese is exclusively produced with milk from healthy cows in extended lactation, the final curd moisture could be controlled. Accordingly, curd firmness could be used as a reference for cutting the curd in cheese manufacturing (Auldist et al., 2010; Frederiksen et al., 2011).

A principal component analysis plot (not shown) revealed that some animals that produced milk with constantly higher casein concentration throughout the lactation and, accordingly, superior cheesemaking properties are of great importance for both cheese industry and farmers. By increasing the bulk levels of protein and changing the protein composition through breeding or genomic selection, losses during the cheese manufacturing could potentially be reduced. In addition, recent work suggested that cows managed for CInt up to 19 mo were able to produce at least equivalent amounts of ECM per feeding day when compared with cows undergoing the traditional 12-mo CInt (Lehmann et al., 2016). However, further studies on the associations between protein-related traits driving milks with superior cheesemaking parameters, lactation persistency, and productive traits of cows managed for extended lactations are needed to identify individuals with superior overall performance.

The differences between the sensory quality of pasteurized whole milk produced in P1 and P3 are mainly due to fat-related attributes, as the fat concentration of the milk collected in P3 was approximately $0.7 \mathrm{~g} / 100$ $\mathrm{g}$ higher than in P1. This indicates a clear fat-level direction in the sensory results, which was also reported by Frøst et al. (2001) when studying the fat perception in pasteurized milk. Furthermore, the higher protein concentration in late-lactation milk $(\sim 0.6 \mathrm{~g} / 100 \mathrm{~g})$ may have contributed to the perceived creaminess as well. Saltiness, previously signalized by Bertilsson et al. (1997) as the only quality deviation in milk collected in late extended lactation, was not detected by the sensory panel in our study, and hence not included as a sensory descriptor. However, Bertilsson et al. (1997) stressed that a tendency for salty taste was just noticed in milk from cows at low production level (i.e., 10 to $15 \mathrm{~kg} / \mathrm{d}$ ), which is well below the average production level of our experimental herd. We found no apparent explanation for the higher grades for off-flavor related attributes for milks from P1, especially for metallic aroma and cardboard flavor, as those sensory attributes are linked to lipid oxidation (Hedegaard et al., 2006), which is not expected here. Therefore, we hypothesized that the elevated fat concentration probably masked the perception of those attributes in extended-lactation milk.

\section{CONCLUSIONS}

The present study did not find any evidence to which milk produced by healthy high-yielding Holstein cows at later stages of an 18-mo CInt would be significantly compromised in quality when compared with milk produced in mid lactation. The increased $\mathrm{Cl}^{-}$concentration at the late lactation period (385-420 DIM) seemed to be related to the concomitant decrease in lactose concentration. Other parameters related to impaired milk-blood barrier, such as SCC, level of free amino terminals, casein-to-total protein ratio, conductivity, and $\mathrm{pH}$ remained unchanged when compared with the mid lactation period (140-175 DIM). This, in association with the increases in protein and casein concentration, resulted in superior cheesemaking properties (RCT, CFR, G'max, and wet and dry curd yield) at later 
stages of extended lactation (i.e., 280-315 and 385-420 DIM). Accordingly, late extended-lactation milk did not present sensory demerits when compared with midlactation milk. Furthermore, feeding cows either highor low-density diets during the mobilization period in early lactation did not exert relevant carryover effect on milk composition in the extended lactation period. Our results suggest that milk sensory quality and cheesemaking properties should not be a concern against managing high-yielding healthy cows fed nutritionally balanced diets to achieve extended lactations.

\section{ACKNOWLEDGMENTS}

The authors are grateful for the technical assistance of Camilla Bjerg Kristensen and Nina Eggers (both from Department of Food Science, Aarhus University, Denmark). The present study is part of the PhD work of Guilherme de Moura Maciel and was financially supported by CAPES (Brasília, Brazil), The Danish Council for Strategic Research (Copenhagen, Denmark) as part of the REPROLAC project, as well as by Arla Foods amba (Viby J, Denmark) and Aarhus University, Denmark.

\section{REFERENCES}

ASTM. 1986. Physical Requirement Guidelines For Sensory Evaluation Laboratories. J. Eggert and K. Zook, ed. ASTM International, West Conshohocken, PA.

Athie, F., K. C. Bachman, H. H. Head, M. J. Hayen, and C. J. Wilcox. 1996. Estrogen administered at final milk removal accelerates involution of bovine mammary gland. J. Dairy Sci. 79:220-226. http:// dx.doi.org/10.3168/jds.S0022-0302(96)76354-3.

Auldist, M., S. Coats, G. Rogers, and G. McDowell. 1995. Changes in the composition of milk from healthy and mastitic dairy cows during the lactation cycle. Aust. J. Exp. Agric. 35:427-436. http:// dx.doi.org/10.1071/EA9950427.

Auldist, M. J., S. Coats, B. J. Sutherland, J. J. Mayes, G. H. McDowell, and G. L. Rogers. 1996. Effects of somatic cell count and stage of lactation on raw milk composition and the yield and quality of Cheddar cheese. J. Dairy Res. 63:269-280.

Auldist, M. J., C. Grainger, A. V. Houlihan, J. J. Mayes, and R. P. W. Williams. 2010. Composition, coagulation properties, and cheesemaking potential of milk from cows undergoing extended lactations in a pasture-based dairying system. J. Dairy Sci. 93:14011411. http://dx.doi.org/10.3168/jds.2009-2727.

Auldist, M. J., G. O'Brien, D. Cole, K. L. Macmillan, and C. Grainger. 2007. Effects of varying lactation length on milk production capacity of cows in pasture-based dairying systems. J. Dairy Sci. 90:3234-3241. http://dx.doi.org/10.3168/jds.2006-683.

Bertilsson, J., B. Berglund, G. Ratnayake, K. Svennersten-Sjaunja, and H. Wiktorsson. 1997. Optimising lactation cycles for the highyielding dairy cow. A European perspective. Livest. Prod. Sci. 50:5-13. http://dx.doi.org/10.1016/S0301-6226(97)00068-7.

Borman, J. M., K. L. Macmillan, and J. Fahey. 2004. The potential for extended lactations in Victorian dairying: A review. Aust. J. Exp. Agric. 44:507-519. http://dx.doi.org/10.1071/EA02217.

Bossen, D., and M. R. Weisbjerg. 2009. Allocation of feed based on individual dairy cow live weight changes. Livest. Sci. 126:273-285. http://dx.doi.org/http://dx.doi.org/10.1016/j.livsci.2009.07.011.
Capuco, A. V., R. M. Akers, and J. J. Smith. 1997. Mammary growth in Holstein cows during the dry period: Quantification of nucleic acids and histology. J. Dairy Sci. 80:477-487. http://dx.doi. org/10.3168/jds.S0022-0302(97)75960-5.

Coulon, J. B., and L. Pérochon. 1998. Modelling the effect of the stage of pregnancy on milk composition. Anim. Sci. 67:413-419. http:// dx.doi.org/10.1017/S1357729800032811.

Coulon, J. B., L. Pérochon, and F. Lescourret. 1995. Modelling the effect of the stage of pregnancy on dairy cows' milk yield. Anim. Sci. 60:401-408. http://dx.doi.org/10.1017/S1357729800013278.

Coulon, J. B., I. Verdier, P. Pradel, and M. Almena. 1998. Effect of lactation stage on the cheesemaking properties of milk and the quality of Saint-Nectaire-type cheese. J. Dairy Res. 65:295-305.

Dalsgaard, T. K., J. H. Nielsen, and L. B. Larsen. 2007. Proteolysis of milk proteins lactosylated in model systems. Mol. Nutr. Food Res. 51:404-414. http://dx.doi.org/10.1002/mnfr.200600112.

Dessauge, F., V. Lollivier, B. Ponchon, R. Bruckmaier, L. Finot, S. Wiart, E. Cutullic, C. Disenhaus, S. Barbey, and M. Boutinaud. 2011. Effects of nutrient restriction on mammary cell turnover and mammary gland remodeling in lactating dairy cows. J. Dairy Sci. 94:4623-4635. http://dx.doi.org/10.3168/jds.2010-4012.

Frederiksen, P. D., M. Hammershøj, M. Bakman, P. N. Andersen, J. B. Andersen, K. B. Qvist, and L. B. Larsen. 2011. Variations in coagulation properties of cheese milk from three Danish dairy breeds as determined by a new free oscillation rheometry-based method. Dairy Sci. Technol. 91:309-321. http://dx.doi.org/10.1007/s13594011-0018-5.

Frøst, M. B., G. Dijksterhuis, and M. Martens. 2001. Sensory perception of fat in milk. Food Qual. Prefer. 12:327-336. http://dx.doi. org/10.1016/S0950-3293(01)00018-0.

Gaillard, C., H. Barbu, M. T. Sørensen, J. Sehested, H. Callesen, and M. Vestergaard. 2016a. Milk yield and estrous behavior during eight consecutive estruses in Holstein cows fed standardized or high energy diets and grouped according to live weight changes in early lactation. J. Dairy Sci. 99:3134-3143. http://dx.doi. org $/ 10.3168 /$ jds.2015-10023.

Gaillard, C., N. C. Friggens, M. Taghipoor, M. R. Weisbjerg, J. O. Lehmann, and J. Sehested. 2016b. Effects of an individual weightadjusted feeding strategy in early lactation on milk production of Holstein cows during extended lactation. J. Dairy Sci. 99:22212236. http://dx.doi.org/10.3168/jds.2015-10359.

Gaillard, C., M. Vestergaard, M. R. Weisbjerg, and J. Sehested. 2016c. Effects of live weight adjusted feeding strategy on plasma indicators of energy balance in Holstein cows managed for extended lactation. Animal 10:633-642. http://dx.doi.org/10.1017/ S175173111500258X.

Grainger, C., M. J. Auldist, G. O'Brien, K. L. Macmillan, and C. Culley. 2009. Effect of type of diet and energy intake on milk production of Holstein-Friesian cows with extended lactations. J. Dairy Sci. 92:1479-1492. http://dx.doi.org/10.3168/jds.2008-1530.

Grufferty, M. B., and P. F. Fox. 1988. Milk alkaline proteinase. J. Dairy Res. 55:609-630. http://dx.doi.org/10.1017/S0022029900033409.

Guinee, T. P., C. B. Gorry, D. J. O'Callaghan, B. T. O'Kennedy, N. O'Brie, and M. A. Fenelon. 1997. The effects of composition and some processing treatments on the rennet coagulation properties of milk. Int. J. Dairy Technol. 50:99-106. http://dx.doi. org/10.1111/j.1471-0307.1997.tb01747.x.

Guinee, T. P., B. T. O'Kennedy, and P. M. Kelly. 2006. Effect of milk protein standardization using different methods on the composition and yields of cheddar cheese. J. Dairy Sci. 89:468-482. http:// dx.doi.org/10.3168/jds.S0022-0302(06)72110-5.

Hedegaard, R. V., D. Kristensen, J. H. Nielsen, M. B. Frøst, H. Ostdal, J. E. Hermansen, M. Kröger-Ohlsen, and L. H. Skibsted. 2006. Comparison of descriptive sensory analysis and chemical analysis for oxidative changes in milk. J. Dairy Sci. 89:495-504. http:// dx.doi.org/10.3168/jds.S0022-0302(06)72112-9.

Hurtaud, C., H. Rulquin, M. Delaite, and R. Vérité. 1995. Appréciation de l'aptitude fromagère des laits de vaches individuels. Tests d'aptitude fromagère et rendement fromager de fabrication. Ann. Zootech. 44:385-398. http://dx.doi.org/10.1016/0003424X(96)89762-X. 
ISO. 1993. ISO 8586-1. General guidelines for the selection, training and monitoring of assessors. International Organization for Standardization, Geneva, Switzerland.

Knight, C. H. 2005. Extended lactation: Turning theory into reality. Adv. Dairy Technol. 17:113-123.

Kolver, E. S., J. R. Roche, C. R. Burke, J. K. Kay, and P. W. Aspin. 2007. Extending lactation in pasture-based dairy cows: I. Genotype and diet effect on milk and reproduction. J. Dairy Sci. 90:5518-5530. http://dx.doi.org/10.3168/jds.2007-0324.

Korycha-Dahl, M., B. R. Dumas, N. Chene, and J. Martal. 1983. Plasmin activity in milk. J. Dairy Sci. 66:704-711. http://dx.doi. org/10.3168/jds.S0022-0302(83)81848-7.

Larsen, L. B., P. L. H. McSweeney, M. G. Hayes, J. B. Andersen, K. L. Ingvartsen, and L. Kelly. 2006. Variation in activity and heterogeneity of bovine milk proteases with stage of lactation and somatic cell count. Int. Dairy J. 16:1-8. http://dx.doi.org/10.1016/j. idairyj.2005.01.009.

Lehmann, J. O., J. G. Fadel, L. Mogensen, T. Kristensen, C. Gaillard, and E. Kebreab. 2016. Effect of calving interval and parity on milk yield per feeding day in Danish commercial dairy herds. J. Dairy Sci. 99:621-633. http://dx.doi.org/10.3168/jds.2015-9583.

Lehmann, J. O., L. Mogensen, and T. Kristensen. 2014. Extended lactations may improve cow health, productivity and reduce greenhouse gas emissions from organic dairy production. Org. Agric. 4:295-299. http://dx.doi.org/10.1007/s13165-014-0070-6.

Lenth, R., and M. Harvé. 2015. lsmeans: Least-Squares Means. R Package version 2.15. Accessed Oct. 10, 2015. https://cran.rproject.org/web/packages/lsmeans/.

Lucey, J. 1996. Cheesemaking from grass based seasonal milk and problems associated with late-lactation milk. Int. J. Dairy Technol. 49:59-64. http://dx.doi.org/10.1111/j.1471-0307.1996.tb02491.x.

Lucey, J. A., and P. F. Fox. 1992. Rennet coagulation properties of late-lactation milk: Effect of $\mathrm{pH}$ adjustment, addition of $\mathrm{CaCl} 2$, variation in rennet level and blending with mid-lactation milk. Ir. J. Agric. Food Res. 31:173-184.

Lucey, J. A., P. S. Kindstedt, and P. F. Fox. 1992. Seasonality: Its impact on the production of good quality Mozzarella cheese. Pages 41-47 in 3rd Cheese Symposium. T.M. Cogan, ed. Moorepark, Fermoy, Cork, Ireland.

Nicholas, G. D., M. J. Auldist, P. C. Molan, K. Stelwagen, and C G. Prosser. 2002. Effects of stage of lactation and time of year on plasmin-derived proteolytic activity in bovine milk in New Zealand. J. Dairy Res. 69:533-540.

NRC. 2001. Nutrient Requirements of Dairy Cattle. Natl. Acad. Press, Washington, DC.

Olori, V. E., S. Brotherstone, W. G. Hill, and B. J. McGuirk. 1997. Effect of gestation stage on milk yield and composition in Holstein Friesian dairy cattle. Livest. Prod. Sci. 52:167-176. http://dx.doi. org/10.1016/S0301-6226(97)00126-7.

Österman, S., and J. Bertilsson. 2003. Extended calving interval in combination with milking two or three times per day: Effects on milk production and milk composition. Livest. Prod. Sci. 82:139149. http://dx.doi.org/10.1016/S0301-6226(03)00036-8.

Ostersen, S., J. Foldager, and J. E. Hermansen. 1997. Effects of stage of lactation, milk protein genotype and body condition at calving on protein composition and renneting properties of bovine milk. J. Dairy Res. 64:207-219.

Pinheiro, J., D. Bates, S. DebRoy, D. Sarkar, and R Core Team. 2014. nlme: Linear and Nonlinear Mixed Effects Models. R Package version 3.1-118. Accessed Oct. 10 2015. http://cran.r-project.org/ package $=$ nlme $/$.

Politis, I. 1996. Plasminogen activator system: Implications for mammary cell growth and involution. J. Dairy Sci. 79:1097-1107. http://dx.doi.org/10.3168/jds.S0022-0302(96)76463-9.

Poulsen, N. A., A. J. Buitenhuis, and L. B. Larsen. 2015. Phenotypic and genetic associations of milk traits with milk coagulation properties. J. Dairy Sci. 98:2079-2087. http://dx.doi.org/10.3168/ jds.2014-7944

R Development Core Team. 2015. R: A language and Environment for Statistical Computing. Version 3.1.2. R Foundation for Statistical Computing, Vienna, Austria. Accessed Feb. 16, 2015. http:// http://www.r-project.org.

Rehn, H., B. Berglund, U. Emanuelson, G. Tengroth, and J. Philipsson. 2000. Milk production in Swedish dairy cows managed for calving intervals of 12 and 15 months. Acta Agric. Scand. A Anim. Sci. 50:263-271. http://dx.doi.org/10.1080/090647000750069458.

Roche, J. R. 2003. Effect of pregnancy on milk production and bodyweight from identical twin study. J. Dairy Sci. 86:777-783. http:// dx.doi.org/10.3168/jds.S0022-0302(03)73659-5.

Shennan, D. B., and M. Peaker. 2000. Transport of milk constituents by the mammary gland. Physiol. Rev. 80:925-951.

Sjaunja, L. O., L. Bævre, L. Junkkarinen, J. Pedersen, and J. Setälä. 1991. A Nordic proposal for an energy corrected milk (ECM) formula. Pages 156-157 in Performance Recording of Animals: State of the Art, 1990. EAAP publication 50. P. Gaillon and Y. Chabert, ed. Centre for Agricultural Publishing and Documentation (PUDOC), Wageningen, the Netherlands.

Sorensen, A., D. D. Muir, and C. H. Knight. 2008. Extended lactation in dairy cows: effects of milking frequency, calving season and nutrition on lactation persistency and milk quality. J. Dairy Res. 75:90-97. http://dx.doi.org/10.1017/S0022029907002944.

Stefanon, B., M. Colitti, G. Gabai, C. H. Knight, and C. J. Wilde. 2002. Mammary apoptosis and lactation persistency in dairy animals. J. Dairy Res. 69:37-52.

Stelwagen, K. 2002. Biosynthesis and Secretion. Pages 1842-1847 in Encyclopedia of Dairy Sciences. Elsevier, Oxford, UK.

Tomic, O., G. Luciano, A. Nilsen, G. Hyldig, K. Lorensen, and T. Næs. 2009. Analysing sensory panel performance in a proficiency test using the PanelCheck software. Eur. Food Res. Technol. 230:497511. http://dx.doi.org/10.1007/s00217-009-1185-y.

Volden, H., ed. 2011. NorFor-The Nordic feed evaluation system. Wageningen Academic Publishers, Wageningen, the Netherlands.

Wedholm, A., L. B. Larsen, H. Lindmark-Månsson, A. H. Karlsson, and A. Andrén. 2006. Effect of protein composition on the cheese-making properties of milk from individual dairy cows. J. Dairy Sci. 89:3296-3305. http://dx.doi.org/10.3168/jds.S00220302(06)72366-9.

Wei, T. 2013. corrplot: Visualization of a correlation matrix. R Package version 0.73 